\title{
PROSES EVOLUSI MASYARAKAT ISLAM
}

\author{
Isti'anah Abubakar \\ Dosen Tarbiyah Jurusan PAI UIN Maliki Malang. Telp: 081333501272 \\ email: istianah.ab@gmail.com
}

\begin{abstract}
The success of Muhammad in building an Islamic society could be felt until today. The alteration of Islamic society has been an evolution which could be used as an inspiration to had a better society in the future. The society before Islam Identically recognized as a community people who ignored the norm of humanity, selfish, rude, barbarous, and ashâbiyah qaumiyyah. This alteration to be a humanity society was the perfect evolution. Therefore, this study will explore the basic of philosophical evolution and its process which can be implemented in building a civil society.

Keberhasilan Nabi Muhammad dalam membangun masyarakat Islam masih bisa dirasakan sampai saat ini. Perubahan masyarakat Islam merupakan proses evolusi yang dapat dijadikan inspirasi dalam membentuk masyarakat masa depan. Masyarakat Pra Islam identik dengan masyarakat yang jauh dari nilainilai kemanusiaan. Perilaku egois, biadab dan ashâbiyah qaumiyyah adalah gambaran kongkritnya. Perubahan masyarakat Pra Islam menjadi masyarakat yang humanis merupakan proses evolusi yang sempurna. Paper ini dimaksudkan membahas landasan filosofis dan tahapan proses evolusi masyarakat yang dapat diimplementasikan dalam membangun masyarakat madani
\end{abstract}

Key word: Islamic society, evolution, humanity, civil society

\section{Pendahuluan}

Masyarakat 'sakit' adalah istilah Marzuki Umar Saabah dalam menggambarkan kondisi masyarakat saat ini. Manusia bergeser dari wujud kemanusiannya dan diganti dengan wujud produktivitas yang dicapainya. Manusia tidak lagi melihat manusia sebagai sosok yang bebas dari titel, 
jabatan, prestasi dan harta benda. Artinya hubungan kemanusiaan disandarkan pada seberapa tinggi titel, jabatan dan banyaknya harta benda yang dimiliki. Semakin tinggi titel, jabatan dan harta yang dicapai dan dimiliki, maka akan semakin lancar hubungan yang dijalin demikian juga sebaliknya. Ini menunjukkan bahwa hubungan kemanusiaan dan tatanan masyarakat yang terjadi berdasarkan pamrih, tanpa ada nilai-nilai luhur di dalamnya. Kondisi ini menjadikan tatanan masyarakat jauh dari semangat ukhuwah, kebersamaan dan kepedulian sosial. Masyarakat saat ini adalah masyarakat yang bercirikan: (a) materialisme, (b) individualisme, nilai individu mengatasi nilai sosial, (c) sekulerisme, usaha dan perhatian hanyut dalam soal soal dunia, (d) agnotisima, beragama tidak, tidak beragama, tidak hirau tentang ketuhanan, (e) kapitalisme, individualisme dalam tata ekonomi, (f) ateisme, materialisme dalam kepercayaan Ketuhanan, (g) sosialisme, kolektivisma dalam ekonomi, (h) komunisme, (i) kristenisasi, penasranian orang-orang Islam untuk menopang kekuasaan politik dan ekonomi Barat (Gazalba, 1976: 32). Deskripsi Marzuki dan Gazalba di atas menegaskan bahwa nilai-nilai yang seharusnya digunakan sebagai pedoman kehidupan bersama tinggal sekedar pengetahuan dan bukan sebagai guide di dalam tindakan untuk mencapai tujuan bersama. Inilah gambaran masyarakat sebelum datangnya Islam, masyarakat jahiliyah masyarakat yang belum mengenal ajaran tauhid yang mengajarkan norma kemanusiaan (Syafiq, 2002: 19).

Masyarakat menurut Linton dalam Gazalba merupakan kelompok manusia yang sudah lama hidup dan bekerjasama, dalam konteks ini maka pembentukan masyarakat tidak terjadi secara tiba-tiba namun melalui sebuah proses salah satunya evolusi (Gazalba, 1976: 56). Evolusi dipahami sebagai proses perkembangan yang terjadi secara perlahan namun pasti, konteks ini sangat relevan untuk mendeskripsikan tatanan masyarakat yang dibentuk Nabi Muhammad SAW. Perkembangan masyarakat yang dulunya jauh dari norma kemanusiaan, masyarakat yang dulunya sakit berkembang ke tatanan masyarakat yang menjunjung tinggi norma kemanusiaan. Proses pembentukan masyarakat ini perlu ditelaah lebih lanjut terkait nilai-nilai filosofis, tahapan dan langkah kongkrit yang digunakan Nabi Muhammad SAW dalam membentuk masyarakat Islam, masyarakat yang hidup dan bekerjasama berdasarkan ajaran Islam yaitu ajaran yang membawa kedamaian bagi pemeluknya.

\section{Masyarakat Jahiliyah}

Masyarakat jahiliyah merupakan laqab untuk masyarakat pra Islam 
dimaknai sebagai susunan masyarakat yang jauh dari kedamaian dan keselamatan dalam konteks global. Ini sesuai dengan deskripsi Muhammad al Ghazali dalam Fiqh Sirah, bahwa interaksi masyarakat (khususnya di Makkah) meskipun aman dan membawa berkah namun keistimewaan tersebut tidak didukung oleh kehangatan dalam pergaulan dan persaudaraan (Taqiyudin, 2010: 94 ). Jahiliyah dalam konteks ini bukan lawan kata dari 'ilm namun lawan kata dari hilm (lemah lembut), sabr (sabar) dan adab. Jadi yang dimaksud dengan jahiliyah adalah perilaku kasar, biadab dan tidak bermoral, tidak mengindahkan sopan santun. Karakteristik masyarakat jahiliyah bisa ditinjau dari 4 aspek sesuai lafadz jahiliyah yaitu: Pertama, masalah aqidah (keagamaan, kepercayaan) diatur dalam surat al Imran (154), kedua masalah perilaku, diatur dalam surat al Fath (26) dan hukum yang diterapkan dalam masyarakat dalam surat al Maidah (50), ketiga perlakukan terhadap wanita dalam al Ahzab (33) dan keempat terkait mentalitas yang terpusat pada sifat kibr (takabbur). Keempat karakteristik di atas bisa dibahas ke dalam 3 ranah yaitu (a) aqidah, masyarakat jahiliyah merupakan masyarakat yang jauh dari ketauhidan, (b) kemasyarakatan, perilaku bermasyarakat yang jauh dari norma kemanusiaan dan (c) politik, karakteristik kekuasaan yang mengistimewakan bangsawan, orang berharta dalam tatanan masyarakatnya sebagai basis dalam berinteraksinya

Pada aspek aqidah, masyarakat jahiliyah identik dengan masyarakat polytheistic. Adapun bentuk politheisme masyarakat jahiliyah antara lain: (a) penyembahan berhala diatur dalam surat al A'raf (138), (b) rahib diatur dalam surat at Taubah (31) , (c) dan bentuk lain dalam surat al Hijr (96) dan surat al Baqarah (92).

Pada aspek kemasyarakatan, dipahami sebagai gambaran interaksi masyarakat dan yang sangat menonjol adalah interaksinya terhadap perempuan diatur dalam surat an Nisa (22). Masyarakat bermusuhan satu sama lain dan menjadikan nasab dan kedudukan sebagai prasyarat utama dalam berinteraksi.

Pada aspek politik, landasan hukum yang digunakan adalah hukum rimba, siapa yang kuat dia yang menang. Hal ini menyebabkan banyaknya peperangan yang dilakukan, baik karena untuk survival, maupun harga diri. Beberapa ilmuwan menyebutkan terjadi 1700 kekerasan, sebagian menyebutkan 1200 kejadian dan sebagian lain 75 peristiwa, yang paling terkenal adalah peristiwa antara bangsa Persia dan Romawi, Adnan dan Qathan, atau Bani Qathan dengan kelompoknya sendiri dan Adnan dengan kelompoknya sendiri 
(Sami', 2010: 25 dan 68).

Intensitas peperangan yang terjadi, secara tidak langsung mengindikasikan tidak adanya rasa safety, jauh dari nilai damai dan selamat dikarenakan interaksi yang digunakan adalah interaksi yang tidak sehat, saling menyakiti. Mengutip pernyataan M. Athiya al Abrasyi, dunia saat itu penuh dengan para penguasa, hakim dan pemuka agama berkomplot menindas rakyat. Hal ini diperkuat dengan pernyataan Thomas Carlyle dalam On Heroes Hero-Worship and The Heroic in History yang dikutip Zuhri (Zuhri, 1981: 5):

"Itulah bangsa Arab (di kala itu) suatu bangsa petualang di gurun pasir, saling berhantam satu sama lain selama berabad-abad, tiada pemimpin yang membimbing mereka dan mendidiknya”.

Hal ini diperkuat dengan pernyataan Debon dalam Taufiq bahwa kebiasaan Arab sebelum Islam sebagai era keruntuhan moralitas manusia (Djamidin, 2009: 15).

Deskripsi negatif di atas merupakan gambaran yang mendominasi tatanan masyarakat pada waktu itu. Namun demikian masih ada kebiasaan baik yang terbentuk, hanya saja kebiasaan baik tersebut tidak mampu menjadi pioner terciptanya tatanan masyarakat yang hangat dan damai. Secara kongkrit dapat dikemukakan, kebiasaan baik dan buruk masyarakat pra Islam sebagai berikut (Antonio, 2010: 78):

\section{Kebiasaan Baik:}

1. Berkata jujur dan Islam datang menguatkannya.

2. Menjamu tamu sebagai penghormatan kepadanya.

3. Menepati janji.

4. Menghormati tetangga dan mengakui pemberian perlindungan kepada orang yang membutuhkan.

5. Sabar dan kuat.

6. Pemberani, suka menolong dan berwibawa.

7. Menghormati tanah haram dan bulan suci dengan tidak melakukan peperangan kecuali terpaksa.

\section{Kebiasaan Buruk:}

1. Mengubur hidup-hidup bayi perempaun (QS at Takwir: 8-9).

2. Membunuh anak-anak karena takut miskin da kelaparan (QS al Israa': 31).

3. Minum Khamr, berjudi, berkurban untuk berhala, mengundi nasib (QS al Maidah: 9). 
4. Kesukaan wanita bersolek dan kecenderungan mereka mengambil laki-laki sebagai piaraan (QS An Nisa': 25).

5. Fanatisme kabilah dan kesukuan yang menyebabkan sebagian mereka dengan sebagian yang lain menyerang, merampas, merampok.

6. Karena sombong dan angkuh mereka tidak mau bekerja menjadi pandai besi dan meyerahkan pekerjaan itu ke budak.

Ketiga ranah masyarakat jahiliyah, aqidah, kemasyarakatan dan politik menunjukkan bahwa tatanan masyarakat, hubungan kemanusiaan yang tercipta merupakan hubungan simbolik materialisme, artinya hubungan yang tercipta karena adanya timbal balik yang diperoleh bukan berdasarkan nilai luhur yang disepakati. Hubungan kemanusiaan dengan mengharap timbal balik sebagai simbolnya bersifat temporer. Hal inilah yang mendominasi tatanan masyarakat jahiliyah dimana hubungan kemanusiaan mereka terputus ketika salah satunya tidak lagi mendatangkan manfaat.

\section{Masyarakat Islam: Etimologi dan Terminologi}

Masyarakat berasal dari kata syarikat yang tersimpul unsur-unsur pengertian, berhubungan dan pembentukan suatu kelompok atau golongan atau kumpulan yang kemudian identik dengan pergaulan hidup maknanya menjadi sosial al Mujtam'u Al Mujtama' mengandung arti mempertahankan hubungan-hubungan teratur antara seseorang dengan orang lain. Adapun Kuncaraningrat mendefinisikan masyarakat dengan kelompok terbesar dari makhluk-makhluk manusia dimana hidup terjaring suatu kebudayaan yang oleh manusia-manusia tadi dirasakan sebagai satu kebudayaan. Dalam konteks ini, maka masyarakat tidak bisa dipisahkan dengan kebudayaan mengingat kebudayaan adalah hasil, cipta, karsa dan rasa manusia(Gazalba, 1976: 11). Dari definisi di atas maka dapatlah dikatakan bahwa masyarakat merupakan sekelompok orang yang di dalamnya terdapat aturan-aturan pergaulan hidup dalam berbagai bidang kebudayaan yang telah disepakati.

Islam berasal dari kata aslama yang berarti selamat, damai dan sejahtera. Sedangkan secara terminologi, Islam dimaknai sebagai ajaran yang mengajak pemeluknya untuk berperilaku madani (يتخلّق بأخلاق اهل المدن) yaitu suatu perilaku yang mengantarkan pada keselamatan. Islam yang berasal dari kata salam (terdiri dari huruf sin, lam dan mim) dapat dijumpai dalam berbagai bentuk. Secara kuantitas bentuk dari kata salima, maka bentuk kata kerja menempati urutan pertama, sedangkan bentuk fail menempati urutan bisa jadi paling 
sedikit. Perimbangan tersebut mengindikasikan bahwa melakukan kepatuhan masih merupakan hal yang harus dibiasakan mengingat manusia merupakan makhluk yang emosional. Sebaliknya orang yang berhasil melakukan kepatuhan (disebut muslim) sangat sedikit, dapat dipahami bahwa menjadi orang yang patuh merupakan pemenang atas segala tantangan yang dihadapi. Berdasarkan kedua definisi masyarakat dan Islam, maka yang dimaksud masyarakat Islam adalah sekelompok orang yang di dalamnya terdapat aturan-aturan pergaulan hidup dalam berbagai bidang kebudayaan yang telah disepakati yaitu aturan Islam.

Secara historis, Islam merupakan ajaran yang dibawa oleh para Nabi dan Rasul sebelum Nabi Muhammad SAW, dimana ajaran yang mereka bawa selalu mengajak pada keselamatan dan menghormati hak dan kewajiban sesama. Nabi Ibrahim misalnya, mengajak umatnya untuk menyembah Tuhan yang intinya mengajak pada keselamatan manusia, demikian juga Nabi Musa yang menyelematakan manusia dari Firaun yang menamakan dirinya Tuhan dan beragam kisa Nabi lainnya. Dalam konteks inilah Nabi Muhammad SAW diposisikan sebagi Nabi penutup, pembawa ajaran yang menyempurnakan ajaran sebelumnya. Bila Islam diibaratkan sebagai rumah, maka para Nabi dan Rasul sebelum Nabi Muhammad SAW secara bertahap telah membangun rumah tersebut dan Nabi Muhammad yang melakukan finishing. Ini berarti bahwa Islam yang dibawa Nabi Muhammad SAW merupakan ajaran yang lengkap dan utuh dikarenakan adanya penyempurnaan dari ajaran-ajaran sebelumnya. Relevansinya dengan masyarakat, bahwa tananan masyarakat Nabi Muhammad merupakan tatanan penyempurna bagi masyarakat sebelumnya dan masa yang akan datang.

\section{Landasan Filosofis Teologis: Pijakan Dasar Pembentukan Masyarakat Islam}

Filosofis teologis dimaknai sebagai spirit yang digunakan dalam membentuk tatanan masyarakat yang ideal, masyarakat yang mengedepankan akidah Islam sebagai asas pembangunan peradabannya, perintah dan larangan Allah sebagai tolak ukur perbuatannya, kebahagian yang didasarkan atas ridho Allah (Antonio, 2010: 9). Konteks ini memperkuat apa yang diungkapkan Muhammad al Ghazali terkait 4 pokok misi dakwah Islam saat di Makkah yaitu (1) al Wihdaniyyah al Mutlaqah adalah ketauhidan secara paripurna, (2) al Dar al Akhirah, (3) Tazkiyatun Nafs, dan (4) kebersamaan dalam komunitas. Keempatnya mengindikasikan bahwa tindakan apapun yang dilakukan dengan 
mengedepankan filosofis teologis akan berdampak positif bagi semua pihak. Sebaliknya, jika keempatnya diabaikan atau bahkan dilakukan secara tidak berurutan akan menghasilkan harapan semu yang jauh dari ideal. Situasi dan kondisi masyarakat pra Islam menjadi bukti kongkrit tidak digunakannya landasan filosfis teologis di atas. Akibatnya , ketidaknyamanan, hukum rimba mendominasi kondisi masyarakat yang ada. Al Wihdaniyyah al Mutlaqah sebagai based spirit akan berdaya guna dengan melibatkan pemahaman akan adanya al Dar al Akhirah (adanya hari akhir). Keterkaitan keempat landasan ini laksana piramida yang saling menunjang dan saling menguatkan. Adapun kongkritnya seperti di bawah ini:

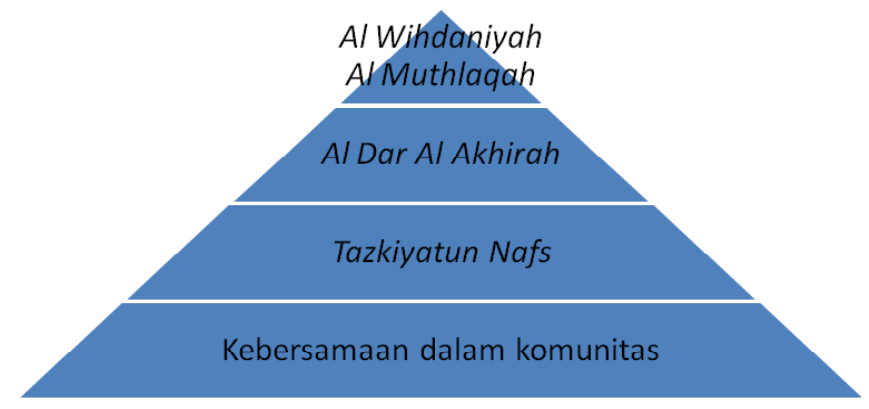

Gambar 1. Piramida kebersamaan dalam suatu komunitas.

\section{Tahapan Pembentukan Masyarakat Islam}

Evolusi masyarakat diketahui dari tahapan pembentukan yang digunakan. Tahapan masyarakat Islam yang dibentuk Nabi Muhammad SAW merupakan tahapan yang perlahan namun pasti. Hal ini terbukti dengan tingginya loyalitas sahabat dalam mengimplementasikan nilai-nilai Islam dalam setiap aktivitasnya. Kondisi tersebut tidak terlepas dari visi pembentukannya yang mengedepankan al Wihdaniyah al Mutlaqah dan ketiga aspek lainnya sebagai dasar geraknya. Pembentukan masyarakat Islam sebagai masyarakat binaan Nabi SAW berada dalam 2 daerah besar yang notabene juga merupakan 2 area utama dakwah Nabi SAW, Makkah dan Madinah (Taqiyudin, 2010: 98). Keistimewaan area masyarakat Islam Mekkah dan Madinah menjadi magnet tersendiri bagi umat Islam sampai sekarang selain saratnya nilai historis di dalamnya. 


\section{Tahap Pertama: Implementasi Nilai-Nilai Bermasyarakat yang Digunakan}

Masyarakat Islam merupakan sekelompok orang yang di dalamnya terdapat aturan-aturan pergaulan hidup dalam berbagai bidang kebudayaan yang telah disepakati yaitu aturan Islam yang berlandaskan persaudaraan, persamaan, penuh toleransi, saling menolong, bermusyawarah dalam memecahkan persoalan dan adil dalam menyikapi segala sesuatu yang kesemuanya mengantarkan pada keselamatan semua pihak. Masyarakat Islam bukanlah masyarakat yang terdiri dari orang-orang Islam, namun harus ditekankan pada masyarakat yang tata pergaulannya berasaskan beberapa asas di atas. Dengan pemahaman semacam ini, maka orang-orang Islam pun tidak bisa mengklaim dirinya masyarakat Islam apabila dalam tata pergaulannya masih mengingkari ke 6 asas tersebut.

Keberhasilan Nabi Muhammad membentuk masyarakat madani selama kurang lebih 23 tahun merupakan keberhasilan yang paling fenomenal. Bila ditelaah, maka ada 6 asas nilai yang digunakan dalam membangun kehidupan bermasyarakat (1) ikho'(persaudaraan ), (2) tasamuh (toleransi ), (3) mu'awanah (saling menolong), (4) musawamah ( persamaan), (5) musyawarah, dan (6) 'adalah (adil). Adapun rincian keenam nilai adalah sebagai berikut:

Persaudaraan (al ikho'), masyarakat sebelum Islam menyandarkan diri pada ikatan suku. Dampak yang ditimbulkan adalah tumbuhnya perasaan acuh terhadap suku yang lain. Dengan kata lain sense of belonging hilang sehingga menimbulkan aktivitas-aktivitas jahiliyah. Maka Nabi pada masa awal awal, mendobrak tatanan masyarakat yang terbentuk berdasarkan suku dan menggantinya dengan ikatan persaudaraan yang didasarkan pada agama. Artinya, selama dalam satu agama maka mempunyai kewajiban untuk menjaga dan melindungi saudara seagama darimanapun dia berasal. Konteks ini secara tidak langsung merubah pola cita masyarakat jahiliyah yang sebelumnya menganggap bahwa saudara adalah saudara yang sama suku (ashabiyah), sehingga diluar suku tidak dianggap saudara sehingga pola laku yang ditampakkan adalah perlakukan-perlakuan yang mendzalimi dan dianggap wajar. Jadi bila dianaologikan, awal pembentukan masyarakat Islam adalah dengan menumbuhkan sense of belonging, menganggap anggota lainnya seperti saudara, seperti anggota tubuh (QS al Hujurat :10).

Saling tolong menolong (al mu'awanah), ketika pola cita persaudaraan (al ikho') telah terbentuk, maka pola laku yang pasti timbul adalah menolong saudaranya semata-mata untuk taat dan patuh kepada-Nya dan menggapai keselamatan bagi semuanya. Secara etimologi, saling tolong menolong adalah 
ta'awana. Ta'awana dalam al Quran dibicarakan dalam satu ayat yaitu al Maidah ayat 2. Bila ditelusuri dalam Mu'jam al Mufahrash, maka kata ta'awana ternyata sangat sedikit. Minimnya jumlah ini tentu saja mengisyaratkan bahwa tolong menolong semata-mata karena Allah merupakan hal yang sangat berat sehingga sangat sedikit orang yang lulus ujian ini. Nabi berhasil menjadikan kaum muslimin pada masa awal bertolong-tolongan semata-mata untuk taqwa tanpa harus ada perjanjian atau $\mathrm{MoU}$ (istilah saat ini) karena menurut mereka cukup diikat dengan janji dan sumpah kepada Allah.

Prinsip ketiga adalah al Musawamah (persamaan). Prinsip ini merupakan faktor utama masuknya seseorang dalam Islam dan menjadi fokus utama dakwah Nabi dinyatakan bahwa karena ajaran egaliter ini maka banyak orang memeluk Islam terutama dari golongan-golongan tertindas seperti Bilal, Yatsir bin Rabah dan lainnya sebaliknya karena adanya egaliter inilah yang merupakan sebab utama kaum Quraisy, kaum berkuasa menolak mentahmentah ajaran agama. Kasus Indonesia pun mengalami kesamaan, rakyat Indonesia yang beragama Hindu Budha tertarik masuk Islam dikarenakan adanya persamaan atau ajaran egaliter (Karim, 2007: 49) dalam memandang seseorang dan bukan berdasarkan kasta.

Selain ajaran egaliter yang ada dalam Islam, prinsip tasamuh (toleransi) yang oleh Gazalba disebut sebagai toleransi sosial agama yaitu seorang muslim tidak mungkin mengaku apalagi membenarkan agama bukan Islam tapi ia wajib mengakui dan membenarkan orang lain beragama lain (QS al Baqarah: 256). Dalam prinsip ini ditekankan untuk tidak memaksakan keyakinan atau kemauan kita pada orang-orang yang berbeda-beda dengan kita (QS al Hujurat: 13 ). Setelah Rasulullah mempersaudarakan kaum Arab berdasarkan agama (ad Din) bukan pada nasab atau suku maka Nabi pun melengkapi tatanan masyarakat dengan ajaran tasamuh dalam hal ini dengan orang-orang Yahudi, Kristen yang ada di Madinah sebelum Nabi hijrah ke kota tersebut. Bukti toleransi beliau tertuang dalam Perjanjian Madinah yang lebih kenal dengan Piagam Madinah pokok-pokok isinya antara lain: (1) kaum Yahudi hidup damai dengan kaum Muslim, kedua belah pihak bebas memeluk dan mengamalkan agamanya masing-masing, (2) mereka bertolong-tolongan, melawan siapa saja yang memerangi mereka. Masing-masing memikul tanggung jawab belanja sendiri dalam perlawanan itu, (3) mereka nasehat-menasehati dan tolong menolong melaksanakan kebajikan dan keutamaan, (4) mereka menghormati Madinah sebagai kota suci. Perselisihan yang berbahaya diserahkan kepada Allah dan Rasulnya, (5) tiap anggota masyarakat wajib diperlindungi keamanan 
dirinya kecuali orang dzalim (Gazalba, 1970: 143)

Musyawarah merupakan prinsip berikutnya yang melengkapi tata cara pergaulan manusia dalam bermasyarakat dalam kondisi apapun. Jika terdapat perbedaan aqidah, maka dianjurkan untuk bertoleransi namun untuk persoalan-persolan lainnya juga diberi panduan untuk selalu bermusyawarah dalam mencapai mufakat. Hal ini secara gambalang dijelaskan dalam surat Al Imran: 159, Al Baqarah: 233 dan Asy Syura: 38. Musyawarah diartikan dengan meninjau pendapat-pendapat agar menjadi jelas mana yang benar di antaranya (Musthafda, 1989: 84). Adapun musyawarah yang pertama kali dalam sejarah Islam adalah masalah khilafah (kepemimpinan) dimana Rasulullah tidak menunjuk tegas akan masalah ini. Sebagai penekanan, maka musyawarah dalam bahasa Karim adalah demokrasi ketuhanan yaitu berkisar mengenai urusan umat. Abul A’la Al Maududi seperti yang dikutip Karim juga menegaskan bahwa demokrasi ketuhanan yang dimaksud adalah pengambilan keputusan tidak harus dengan suara terbanyak melainkan harus dengan suara yang paling cocok dengan bimbingan wahyu (Maududi, 1984: 73).

Al A'dalah (keadilan) merupakan prinsip asasi manusia, dimana manusia manapun dan apapun mengehendaki keadilan. Ketika segala persoalan telah dimusyawarahkan berdasarkan wahyu pabila masih terdapat sisi perselisihan juga harus diselesaikan menurut aturan hukum Allah. Keadilan bersinggungan dengan hukum-hukum perundang-undangan, Islam pun telah memberikan prosedur perundang-undangan sebagai berikut:

1. Ketaatan kepada Allah dan Rasul-Nya didahulukan dari segala ketaatan kepada yang lain.

2. Ketaatan kepada ulil amri datang setelah ketaatan kepada Allah dan Rasul-Nya

3. Ulil amri haruslah terdiri atas rang-orang mukmin.

4. Rakyat mempunyai hak menggugat para penguasa dan pemerintah.

5. Kekuatan penentu dalam setiap perselisihan adalah undang-undang Allah dan Rasul-Nya.

6. Diperlukan adanya suatu badan yang bebas dan merdeka dari tekanan rakyat maupun pengaruh para penguasa agar dapat memberi keputusan dalam perselisihan-perselisihan sesuai undang-undang yang tertinggi yaitu undang-undang Allah dan Rasul-Nya (A'la, 1984: 73).

Implementasi enam nilai di atas merupakan tolak ukur berhasil tidaknya mewujudkan tatanan masyarakat Islam, tatanan masyarakat yang 
mengejawantahkan enam nilai dalam berkehidupan. Keenam nilai tersebut merupakan buah dari al Wihdaniyah al Mutlaqah yang merupakan sasaran utama dakwah Nabi sekaligus landasan yang digunakan untuk menata masyarakat.

Tahap Kedua: Penyiapan SDM Unggul

Tahap kedua selain nilai-nilai bermasyarakat yang dilandasi dengan visi filosofis teologis adalah menyiapkan Sumber Daya Manusia (SDM) yang unggul yang mampu membela dan mendakwakan Islam. Penyiapan SDM ini tentu saja menjadikan Nabi SAW sebagai suri tauladan atau role model dengan deskripsi sebagai berikut (Antonio, 2010: 218):

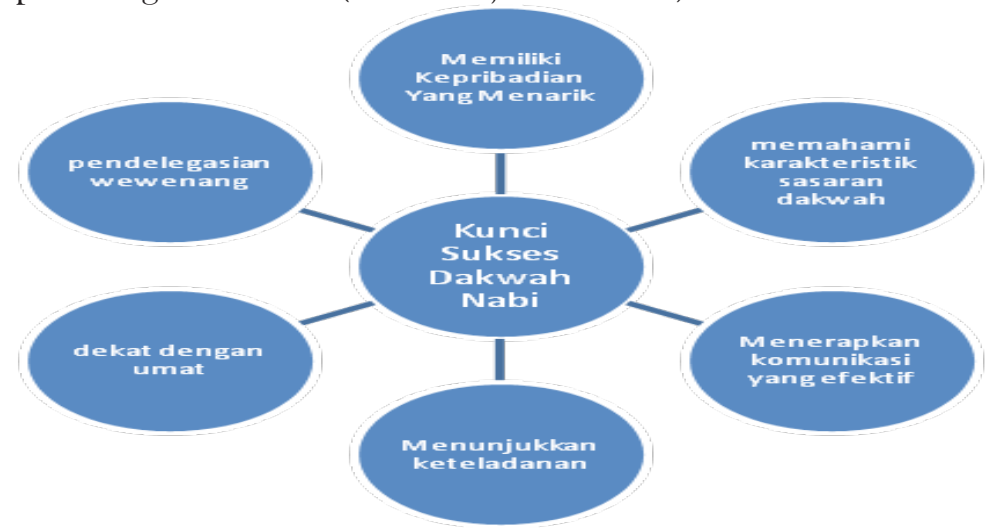

Gambar 2. Keenam indikator kesuksesan dakwah Nabi.

Dari keenam indikator kesuksesan dakwah Nabi terpusat pada kepribadian Nabi sebagai kepribadian yang menarik dan hangat. Corak kepribadian ini sangat diperlukan masyarakat yang saat itu sangat jauh dari kehangatan seperti bahwa masyarakat Makkah tidak didukung oleh kehangatan dalam pergaulan dan persaudaraan (Taqiyudin, 2010: 94). Hal ini memperkuat peran sentral diutusnya Nabi SAW untuk menyempurnakan akhlak perilaku umat. Kepribadian kuat Nabi SAW sebagai role model terbukti mampu menghasilkan sahabat sekaliber khulafa ar Rasyidun dalam membela dan memberi warna masyarakat. Para khalifah tersebut bukanlah sahabat biasa melainkan sahabat dengan kapabilitas tinggi, menjadi teladan dan panutan sahabat lainnya dan bahkan dijamin masuk surga.

\section{Tahap Ketiga: Hijrah ke Yatrib (Madinah)}

Hijrah merupakan momentum Nabi dalam mengimplementasikan ajaran Islam secara Kaffah, tanpa adanya intimidasi dari golongan mayoritas ke 
golongan minoritas. Hijrah Nabi SAW ke Yatrib (Madinah) dilakukan dengan perencanaan matang dengan strategi sebagai berikut: (1) meminta Ali bin Abi Thalib untuk berbaring di ranjangnya, (2) menunjuk sahabat selama proses hijrah seperti Asma yang bertugas untuk menyuplai makanan, (3) melintasi jalan yang berbeda. Ketiga hal tersebut menjadikan hijrah Nabi SAW berhasil dan mendapat sambutan yang hangat dari penduduknya.

Hijrah pada dasarnya dianjurkan dengan alasan: (1) menyelamatkan kemerdekaan dan kehormatan individu, (2) tercapainya kemungkinankemungkinan baru dan ditemukannya lingkungan yang bisa mendukung perjuangan, (3) menyebarluaskan dan mengembangkan ajaran-ajaran Islam di daerah-daerah lain yang membutuhkan (Antonio, 2010: 82). Terkait dengan masyarakat Islam, maka hijrah mutlak dilakukan bilamana intimidasi dari golongan mayoritas tidak bisa dibendung dan membahayakan keyakinan yang sudah terbentuk dengan tetap memastikan situasi dan kondisi daerah yang dijadikan hijrah.

\section{Tahap Keempat: Pendirian Masjid (Base Camp) yang Netral}

Di tempat bersimbuhnya unta Nabi SAW itulah didirikan masjid, tempat yang multi fungsi selain sebagai tempat tinggal Nabi juga tempat berkumpul. Didirikannya masjid sebagai langkah awal hijrah Nabi SAW mengindikasikan bahwa untuk membangun kekuatan dibutuhkan tempat, base camp yang netral, yang tidak memihak golongan siapapun dan manapun. Masjid digunakan Nabi sebagai sarana yang tepat untuk memelihara iman agar tetap kokoh dan mantap, sebagaimana disebutkan dalam al Quran:.

"Hanya yang memakmurkan masjid-masjid Allah ialah orang-orang yang beriman kepada Allah dan hari Kemudian, serta tetap mendirikan shalat, emnunaikan zakat dan tidak takut (kepada siapapun) selain kepada Allah, Maka merekalah orang-orang yang diharapkan termasuk golongan orang-orang yang mendapat petunjuk" (QS at Taubah: 18).

Secara ideal, fungsi masjid sebagai berikut (Antonio, 2010: 190-191): (1) tempat beribadah, (2) tempat menuntut ilmu, (3) tempat pembinaan jamaah, (4) pusat dakwah, (5) pusat kaderisasi umat, (6) basis kebangkitan umat. Menjadikan masjid sebagai poros kegiatan keagamaan dan kemasyarakatan mutlak diperlukan untuk membentuk masyarakat ideal.

\section{Tahap Kelima: Pembentukan Undang-Undang (Piagam Madinah)}

Tahap pembentukan selanjutnya lebih bersifat legal formal, dalam artian menghadirkan konstitusi yang digunakan dalam berinteraksi sesama dan non muslim. Hal ini diperlukan mengingat masyarakat Madinah pasca 
hijrahnya Nabi memiliki 3 varian masyarakat yaitu Islam, Yahudi dan Kristen. Sebagai masyarakat yang mendominasi pemerintahan, tidak serta merta Nabi mengunggulkan Islam dalam berbagai aspeknya, namun tetap berprinsip pada 6 asas nilai yang digunakan dalam membentuk Piagam Madinah sebagai konstitusi pertama dan ideal di dunia. Piagam Madinah inilah yang menjadi landasan kehidupan bermasyarakat yang bersumber dari risalah Islam. Piagam Madinah merupakan Undang-Undang yang diberlakukan untuk masyarakat majemuk, yang mampu mengakomodir berbagai kepentingan. Keberhasilan ini tentu saja bersinergi positif dengan pijakan berfikir yang digunakan dalam merumuskan dan memberlakukan undang-undang yang dibuat yaitu al Wihdaniyah Mutlaqa, Dar al Akhirah dan Tazkiyatun Nafs. Ketiga pijakan inilah yang mampu melahirkan kebersamaan, yang menjadikan rumusan Piagam Madinah disepakati banyak pihak.

\section{Tahap Keenam: Aktualisasi Nilai-Nilai Islam dalam Bermasyarakat (Upaya Kontributif)}

Tahap ini merupakan tahap aktualisasi, tahap pembuktian bahwa model yang dibawa Rasulullah merupakan model ideal dalam kehidupan bermasyarakat. Idealitas Islam oleh Nabi dibumikan dalam kehidupan masyarakat yang sangat praktis sehingga tak lekang oleh zaman. Kondisi inilah yang menyebabkan penganut Islam begitu loyal terhadap ajaran Islam dan menjadikannya pedoman kehidupan dan berkehidupan. Bukti kongkrit aktualisasi nilai-nilai Islam terangkum dalam kalimat 'min al dhulumati ila al Nur' yang mengindikasikan bahwa evolusi yang yang dilakukan Nabi sangat nyata kontribusinya ke arah yang terang benderang.

Model evolusi masyarakat Nabi Muhammad SAW dapat diadopsi oleh siapapun dan kapanpun untuk mewrujudkan situasi hangat dan mendamaikan bagi masyarakat majemuk sekalipun. Landasan pembentukan yang disandarkan pada sesuatu yang hakiki akan menampilkan hubungan yang hakiki pula, tanpa ada batas serta pamrih yang ingin diperoleh. Kondisi ini diperkuat dengan tahapan pembentukannya yang sesuai dengan pola cita dan pola laku masyarakat pada umumnya. Terbentuknya masyarakat sebagai sekelompok orang haruslah diikat dengan nilai-nilai yang dipilih dan disepakati sebagai aturan dalam berhubungan satu sama lain. Tahapan inipun haruslah diperkuat dengan sosok dan profil yang mampu mengejawantahkan dan menjadi modeling pada tahap implementasinya. Secara kongkrit landasan, tahapan proses Nabi dalam membentuk masyarakat Islam sebagai berikut: 

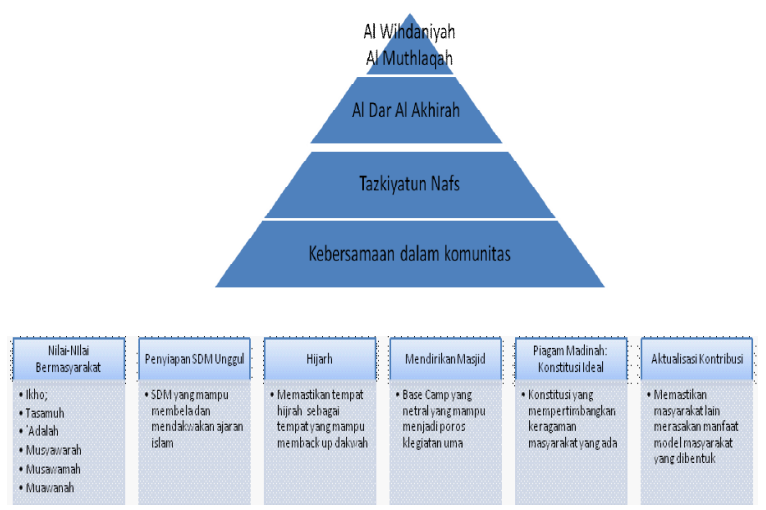

Gambar 3. Model evolusi masyarakat Nabi Muhammad SAW

\section{Simpulan}

Terbentuknya masyarakat didahului dengan visi dan misi yang disepakati bersama, sebagai sesuatu yang dicita-citakan bersama. Pola cita yang disandarkan pada yang hakiki akan menghasilkan pola laku yang hakiki dan langgeng. Sebaliknya pola cita yang disandarkan pada pamrih, dan tujuan jangka pendek akan menghasilkan pola laku bermasyarakat yang temporar pula. Nabi SAW telah membuktikan kesuksesannya dalam membentuk tatanan masyarakat ideal dengan evolusi yang elegan, proses berubah yang berjalan secara berlahan namun pasti tanpa menimbulkan masalah berarti.

\section{Daftar Pustaka}

A'la, al Maududi Abu al Khlafah wa al Mulk. Ted. 1984. Khilafah dan Kerajaan Evaluasi Kritis Atas Sejarah Pemerintahan Islam. Terjemahan oleh Muhammad al Baqir. Bandung: Mizan.

Antonio, Syafii. 2010. Management Super Leadership Nabi Muhammad. Jakarta: Tazkia.

Fuad Abdul Baqi, Muhammad. Tt. Mu’jam Al Mufahrash li Alfadh Al Quran. Jakarta: Angkasa.

Gazalba, Sidi. 1976. Masyarakat Islam Pengantar Sosiologi dan Sosiografi. Jakarta: Bulan Bintang.

Gazalba, Sidi. 1970. Pengantar Sejarah sebagai Ilmu. Jakarta: Bharata.

Djamidin, Taufiq. 2009. Tragedi Pembunuhan 3 Khalifah. Yogyakarta: Pinus 
Book Publisher.

Karim, Abdul. 2007. Islam Nusantara. Pustaka Book Publisher: Yogyakarta.

Madjid, Nurcholis. 1998. Islam Kemodernan dan Keindonesiaan. Jakarta: Mizan.

Musthafda al Maraghi, Ahmad. Ted. 1989. Tafsir al Maraghi. Terjemahan oleh Anshori Umar Sitanggal dkk. Semarang: Toha Putra.

Sami bin Abdullah al Maghluts. 2008. Al Atlas fi Tarikhi Sirah Ar Rasul. Terjemahan oleh Dewi Kurniasari, Atlas Perjalanan Hidup Nabi Muhammad, Napak Tilas Jejak Perjuangan Dan Dakwah Rasulullah, Jakarta: Niaga Swadaya.

Syafiq Mughni. 2002. Pra Islam, Ensiklopedi tematis Jilid 2. Jakarta: Gramedia.

Taqiyudin, Ahmad et al. 2010. Antara Mekkah dan Madinah. Jakarta: Gelora Aksara Pratama.

Zuhri, Saifudin. 1981. Sejarah Kebangkitan Islam dan Perkembangannya di Indonesia. Bandung: al Ma'arif. 